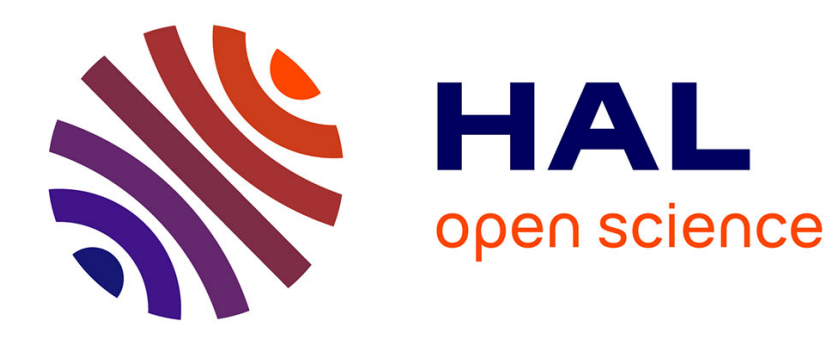

\title{
Paraglacial geomorphology: processes and paraglacial context
}

Denis Mercier, Samuel Etienne

\section{To cite this version:}

Denis Mercier, Samuel Etienne. Paraglacial geomorphology: processes and paraglacial context. Geomorphology, 2008, 95 (1-2), pp.1-2. 10.1016/j.geomorph.2006.07.029 . hal-00281432

\section{HAL Id: hal-00281432 \\ https://hal.science/hal-00281432}

Submitted on 22 May 2008

HAL is a multi-disciplinary open access archive for the deposit and dissemination of scientific research documents, whether they are published or not. The documents may come from teaching and research institutions in France or abroad, or from public or private research centers.
L'archive ouverte pluridisciplinaire HAL, est destinée au dépôt et à la diffusion de documents scientifiques de niveau recherche, publiés ou non, émanant des établissements d'enseignement et de recherche français ou étrangers, des laboratoires publics ou privés. 
The Paraglacial concept: new approaches to glacial landscape evolution (Denis MERCIER and Samuel ETIENNE)

This special issue of Geomorphology grew out of the international conference Shifting lands: new insights into periglacial geomorphology, held at University of Clermont-Ferrand, France, from January $20^{\text {th }}$ to January $22^{\text {nd }}$ 2005. This conference was the Second Scientific Meeting of the European Science Foundation Network SEDIFLUX (Sedimentary Source-to-sink fluxes in cold environments), network directed by Achim Beylich. 95 participants from 15 countries were registered during the Conference which consisted of 2 days and a half of scientific communications. 5 invited keynote papers were given by Prof. Colin Thorn, Prof. Colin Ballantyne, Prof. Kevin Hall, Prof. Hugh French and Prof. John Dixon. 5 thematic sessions (paraglacial dynamics, weathering, permafrost dynamics, periglacial dynamics, nival and snow-related processes) of oral and poster papers have been given ( 31 talks and 23 posters). Accepted abstracts of workshop contributions have been published in a special volume of publications edited by the local Science Meeting organizer (Etienne, 2005). Papers presented here were given during the Paraglacial geomorphology session.

The paraglacial concept was first formalised by Church and Ryder (1972) to defined nonglacial processes that are directly conditioned by glaciation and a period over which paraglacial processes operate. The concept was used the year before by Ryder (1971a, b) to describe alluvial fans in British Columbia following Late Wisconsin deglaciation. Previously, the term "paraglacial" was used several times by Godard (1965) in his geomorphological study of Scotland in both acceptation of the concept, formulated subsequently by Church and Ryder (1972). The paraglacial concept, as defined by Church and Ryder, did not introduce new geomorphological processes, but emphasised the rapid adjustment of deglaciated landscapes to non glacial conditions. Nevertheless, it must be pointed out that one century before, some geomorphological studies described post Little Ice Age readjustment and used different expressions such as "torrential era" (Surell, 1841), "diluvial period" (Martins, 1867), "alluvial fan period" (Girardin, 1910) as paraglacial's synonym (Mercier, 2006).

Recently, Ballantyne (2002) proposed a new and largest definition of paraglacial : "nonglacial earth-surface processes, sediment accumulations, landforms, landsystems and landscapes that are directly conditioned by glaciation and deglaciation". This revised definition extends the use of the term paraglacial from a descriptor of processes to a descriptor of resultant landforms, sediments facies, landscapes and landsystems.

Beyond the value of each paper separately, the collection illustrates how traditional approaches to study cold environments are still judicious, but are being renewed by paraglacial concept with examples chosen in different geomorphological environments: high altitudes (e.g., Karakorum), or high latitudes (e.g., Herschel Island), slopes evolution (e.g., French Alps) or outwash plains (e.g., Spitsbergen). First papers consider paraglacial processes (e.g., adjustement of rock slopes) where as last papers analyse landscapes evolution in a paraglacial context (e.g., post little ice age period for example).

Finally, to conclude this introduction, we would like to acknowledge the effort put forth by over fourteen reviewers of manuscripts for this issue (Prof. C.K. Ballantyne, Dr. Achim A. Beylich, Prof. Arve Elvebakk, Prof. Charles Harris, Prof. Torre Jorgenson, Prof. Brian Luckman, Dr. Denis Mercier, Prof. Jean-Pierre Peulvast, Prof. Chien Lu Ping, Dr Gregor Rachlewicz, Prof. Martha K. Raynolds, Dr Lothar Schrott, Prof. Olav Slaymaker, Prof. Steve Solomon).

\section{References}

Ballantyne. C.K., 2002. Paraglacial geomorphology. Quaternary Science Reviews. 21 : 1935-2017.

Church. M. and Ryder. J.M., 1972. Paraglacial sedimentation : consideration of fluvial processes conditioned by glaciation. Geological Society of America Bulletin. 83 : 3059-3072.

Etienne. S. (ed.). 2005. Shifting lands: new insights into periglacial geomorphology. Clermont-Ferrand, Ed. Séteun, collection géoenvironnement, $126 \mathrm{p}$.

Girardin. P., 1910. Études de cônes de déjections. Annales de Géographie. 105 : 193-207.

Godard. A., 1965. Recherches en géomorphologie en Écosse du Nord-Ouest. Thèse d'État, Université de Paris Sorbonne, Les Belles Lettres, 701 p. 
Martins. C., 1867. Les glaciers actuels et leur ancienne extension pendant la période glaciaire. Imprimerie J. Claye, Paris, 94 p.

Mercier. D., 2006. Le paraglaciaire : évolution d'un concept, in Du continent au bassin versant : théories et pratiques en géographie physique, Hommage au Professeur Alain Godard, Clermont-Ferrand, Presses universitaires Blaise Pascal, collection nature \& sociétés, vol. 4 :.341-353.

Ryder. J.M., 1971a. The stratigraphy and morphology of para-glacial alluvial fans in south-central British Columbia. Canadian Journal of Earth Sciences. 8 : 279-298.

Ryder. J.M., 1971b. Some aspects of the morphometry of paraglacial alluvial fans in south-central British Columbia. Canadian Journal of Earth Sciences. 8 : 1252-1264.

Surell. A., 1841. Étude sur les torrents des Hautes-Alpes. Carillian-Goeuvry éditeurs, Paris, 283 p. (re-issued in 2 volumes by Dunod, $1870: 321$ p., $1872: 386$ p.) 